\title{
Eubacterium tucumanense sp. nov.: an Anaerobic Gram-positive Non-sporeformer Isolated from an Anaerobic Digester
}

\author{
By HECTOR F. DIAZ, * CARLOS G. NÚ̃̃EZ AND FAUSTINO SIÑERÍZ \\ Planta Piloto de Procesos Industriales Microbiológicos - PROIMI, Av. Belgrano y Pje. Caseros, \\ 4000 Tucumán, Argentina
}

(Received 19 July 1988; revised 2 December 1988; accepted 18 July 1989)

An anaerobic bacterium, strain $\mathrm{ED}_{3}$, able to grow on a wide variety of substrates has been isolated from the contents of an anaerobic digester. Cells were non-motile, rod shaped and presented a Gram-positive envelope. Ethanol, methanol, hydrogen plus carbon dioxide, pentoses and a variety of carbohydrates were utilized for growth. Strain $\mathrm{ED}_{3}$ grew best at $37^{\circ} \mathrm{C}$ and at $\mathrm{pH} 6 \cdot 8-7.5$. The $\mathrm{mol} \% \mathrm{G}+\mathrm{C}$ of the DNA was $44.0\left(T_{\mathrm{m}}\right)$. Strain $\mathrm{ED}_{3}$ was named Eubacterium tucumanense sp. nov. and is the type strain (ATCC 49281) for this species.

\section{INTRODUCTION}

The stillage ('vinaza') obtained after the distillation of alcohol produced by yeast fermentation of molasses is a highly concentrated organic wastewater (chemical oxygen demand about 50 $100 \mathrm{~g}$ oxygen $\mathrm{l}^{-1}$ ) that contains excretion products of yeast, yeast cell debris, other compounds present in the sugar-cane juice and pentose sugars. We are interested in organisms that would ferment the pentoses in the anaerobic digester ecosystem, as a first step for the formation of methane.

Some members of the genus Eubacterium ferment pentoses. This genus comprises a large group of strictly anaerobic Gram-positive bacilli which are catalase-negative, non-sporeforming, pleomorphic, and motile or non-motile. They may be saccharoclastic or nonsaccharoclastic but all are chemo-organotrophic. They do not produce large amounts of propionate or lactate, but mixtures of volatile organic acids, from carbohydrates and peptone. Several species are more difficult to grow in liquid than solid media. There are significant variations in the fermentation products when they utilize carbohydrates in defined medium without yeast extract and peptone (Wilkins et al., 1974). Most of the known species produce butyric acid as the principal product of fermentation, together with small quantities of acetic, lactic and succinic acids. Nevertheless, nine species of Eubacterium do not produce butyrate in defined medium when they ferment different carbohydrates (Wegienek \& Reddy, 1982).

The genus Eubacterium can be readily distinguished from morphologically similar genera of anaerobic Gram-positive bacteria, for example Acetobacterium and Clostridium. Members of the genus Acetobacterium differ from those of the genus Eubacterium in their ability to grow by the anaerobic oxidation of hydrogen and the reduction of $\mathrm{CO}_{2}$ to acetic acid, as well as in their ability to carry out only homoacetic fermentations on a limited number of substrates. The mol $\%$ $\mathrm{G}+\mathrm{C}$ of the DNA is 39 (buoyant density) to $43\left(T_{\mathrm{m}}\right)$. Species of Clostridium in which spores are difficult to detect can be differentiated from Eubacterium by demonstration of heat- or alcoholresistance.

Thirty-four species of the genus Eubacterium have been described (Moore \& HoldemanMoore, 1986). The mol \% G $+\mathrm{C}$ of the DNA of the type species, $E$. limosum, is $47\left(T_{\mathrm{m}}\right)$. The $\mathrm{mol} \% \mathrm{G}+\mathrm{C}$ of the DNA of other species examined is $30-55\left(T_{\mathrm{m}}\right)$, indicating that the genus is very heterogeneous. Here we describe a new species, $E$. tucumanense, isolated from an anaerobic digester. 


\section{METHODS}

Isolation of strain $E D_{3}$. Strain $\mathrm{ED}_{3}$ was isolated by enrichment culture on mineral medium (Balch et al., 1979) plus xylose, from the contents of an upflow anaerobic sludge bed reactor used for the treatment of stillage from distilleries that produce alcohol from the fermentation of sugar-cane molasses. Serum bottles $(50 \mathrm{ml})$ containing $10 \mathrm{ml}$ Balch's medium plus $0.05 \%$ xylose, with a nitrogen gas phase, were inoculated with $0.1 \mathrm{ml}$ of the contents of the anaerobic digester and incubated for $15 \mathrm{~d}$ at $37^{\circ} \mathrm{C}$. Dilutions in agar roll tubes with the same medium were incubated for $24 \mathrm{~d}$ at $37^{\circ} \mathrm{C}$. The colonies which developed were punctiform, and less than $1 \mathrm{~mm}$ in diameter. Some were picked and subjected to a new agar dilution series. Isolated colonies were transferred to Balch's medium, without agar, containing $0.5 \%$ xylose, and nitrogen as above, inside an anaerobic chamber (COY Manufacturing Co.) filled with $\mathrm{N}_{2} / \mathrm{CO}_{2} / \mathrm{H}_{2}(80: 10: 10$, by vol.). The culture was transferred monthly.

Media. All culture media were prepared as described by Miller \& Wolin (1974). Balch's medium (Balch et al., 1979) contained, per litre: resazurin $(1 \%, \mathrm{w} / \mathrm{v}), 4 \mathrm{ml}$; mineral solution no. $1,50 \mathrm{ml}$; mineral solution no. $2,50 \mathrm{ml}$; trace minerals solution (Balch et al., 1979), $10 \mathrm{ml}$; vitamin solution (Wolin et al., 1963), $10 \mathrm{ml} ; \mathrm{FeSO}_{4} .7 \mathrm{H}_{2} \mathrm{O}(0.2 \%$ in $0.07 \% \mathrm{HCl}), 1 \mathrm{ml}$. Mineral solution no. 1 contained $\left(\mathrm{g} \mathrm{l}^{-1}\right): \mathrm{K}_{2} \mathrm{HPO}_{4}, 6$. Mineral solution no. 2 contained $\left(\mathrm{g} \mathrm{l}^{-1}\right): \mathrm{KH}_{2} \mathrm{PO}_{4}, 6 ;\left(\mathrm{NH}_{4}\right)_{2} \mathrm{SO}_{4}, 6 ; \mathrm{NaCl}, 12 ; \mathrm{MgSO}_{4} .7 \mathrm{H}_{2} \mathrm{O}, 2 \cdot 45 ; \mathrm{CaCl}_{2} .2 \mathrm{H}_{2} \mathrm{O}, 1 \cdot 50$. Roll tubes were prepared by adding $2 \%(\mathrm{w} / \mathrm{v})$ agar to the same medium. For biochemical tests, PY and PYG media were prepared as described in the VPI Anaerobic Manual (Holdeman \& Moore, 1975).

Isolation of DNA and determination of base composition. DNA was extracted and purified with phenol, according to the method of Saito \& Miura (1963). The mol \% guanine plus cytosine was determined according to Mandel \& Marmur (1968), measuring the absorbance at $260 \mathrm{~nm}$. The melting point $\left(T_{\mathrm{m}}\right)$ was obtained graphically. DNA from Escherichia coli (Sigma) was used as standard. $T_{\mathrm{m}}$ was related to $\mathrm{G}+\mathrm{C}$ using the equation: $\mathrm{mol} \% \mathrm{G}+\mathrm{C}=$ $\left(T_{\mathrm{m}}-53 \cdot 9\right) 2 \cdot 44$.

Analytical techniques. Growth of strain $\mathrm{ED}_{3}$ in liquid cultures was measured using a spectrophotometer (Metrolab Serie UV-Vis), recording the optical density at $560 \mathrm{~nm}$.

Gases were analysed using a gas chromatograph (Gow-Mac Serie 550) equipped with a thermal conductivity detector. A column of silica gel $(180 \times 0.3 \mathrm{~cm})$ was used. Operational conditions were: injection volume, $0.05 \mathrm{ml}$; injection temperature, $80^{\circ} \mathrm{C}$; detector temperature, $100^{\circ} \mathrm{C}$; column temperature, $90^{\circ} \mathrm{C}$; carrier gas, nitrogen at $10 \mathrm{ml} \mathrm{min}^{-1}$

Volatile fatty acids were determined with a gas chromatograph (Gow-Mac Serie 752) equipped with a flame ionization detector and a glass column $(180 \times 0.3 \mathrm{~cm})$ of $10 \% \mathrm{SP}-1200 / \mathrm{H}_{3} \mathrm{PO}_{4}$ on Chromosorb. Operational conditions were: injection volume, $200 \mu \mathrm{l}$ (supernatant of a $72 \mathrm{~h}$ culture); injection temperature, $110^{\circ} \mathrm{C}$; column temperature, $100^{\circ} \mathrm{C}$; carrier gas, nitrogen at $20 \mathrm{ml} \mathrm{min}^{-1}$. Hydrogen flow rate, $60 \mathrm{ml} \mathrm{min}^{-1}$ and air flow rate, $400 \mathrm{ml}^{1} \mathrm{~min}^{-1}$.

Electron microscopy. Cells were fixed with glutaraldehyde $(2.5 \%, \mathrm{w} / \mathrm{v})$ in $0.1 \mathrm{M}$-phosphate buffer $\mathrm{pH} 7.8$ and then subjected to $1 \%(\mathrm{w} / \mathrm{v}) \mathrm{OsO}_{4}$, dehydrated in acetone and embedded in Epon-Araldite. Thin sections were stained with uranyl acetate $(2.0 \%, \mathrm{w} / \mathrm{v})$ for $20 \mathrm{~min}$ and lead citrate $(2.0 \%, \mathrm{w} / \mathrm{v})$ for $5 \mathrm{~min}$, and then observed with an electron microscope (Zeiss 109).

\section{RESULTS AND DISCUSSION}

Strain $\mathrm{ED}_{3}$ conformed to the major characteristics of the genus Eubacterium: non-sporing Gram-positive rods, obligately anaerobic, chemo-organotrophic, producing mixtures of organic acids, including butyric, acetic and formic acids, from carbohydrates or peptone.

The structure of the cell envelope of strain $\mathrm{ED}_{3}$ is shown in Fig. 1. The cell wall has a typical Gram-positive structure, with some resemblance to those reported for Acetobacterium woodii (Mayer \& Schoberth, 1977) and 'Butyribacterium methylotrophicum' (Zeikus et al., 1980). Cells were usually present in pairs. No spores were seen either by phase-contrast microscopy or after staining with malachite green. No growth occurred after heating the culture at $70-80^{\circ} \mathrm{C}$ for $10 \mathrm{~min}$.

Colonies on the roll tubes were punctiform, circular, entire, convex and translucent, reaching about $0.5 \mathrm{~mm}$ in diameter after $21 \mathrm{~d}$ incubation at $37^{\circ} \mathrm{C}$. Growth was enhanced by adding $15 \%$ $(\mathrm{v} / \mathrm{v})$ rumen fluid to the medium. Cultures were catalase negative. Biochemical tests were performed on PY medium as described by Holdeman \& Moore (1975) (Table 1).

Strain $\mathrm{ED}_{3}$ used $\mathrm{CO}_{2}$ plus $\mathrm{H}_{2}$ for growth, acetate being the main product; the doubling time in these conditions was $43 \mathrm{~h}$. Doubling times with sugars as carbon source were: xylose, $26 \mathrm{~h}$; arabinose, $24 \mathrm{~h}$; glucose, $10 \mathrm{~h}$; and fructose, $12 \mathrm{~h}$. The organism slowly fermented ethanol (doubling time $72 \mathrm{~h}$ ). The fermentation balance with xylose as carbon source is shown in 


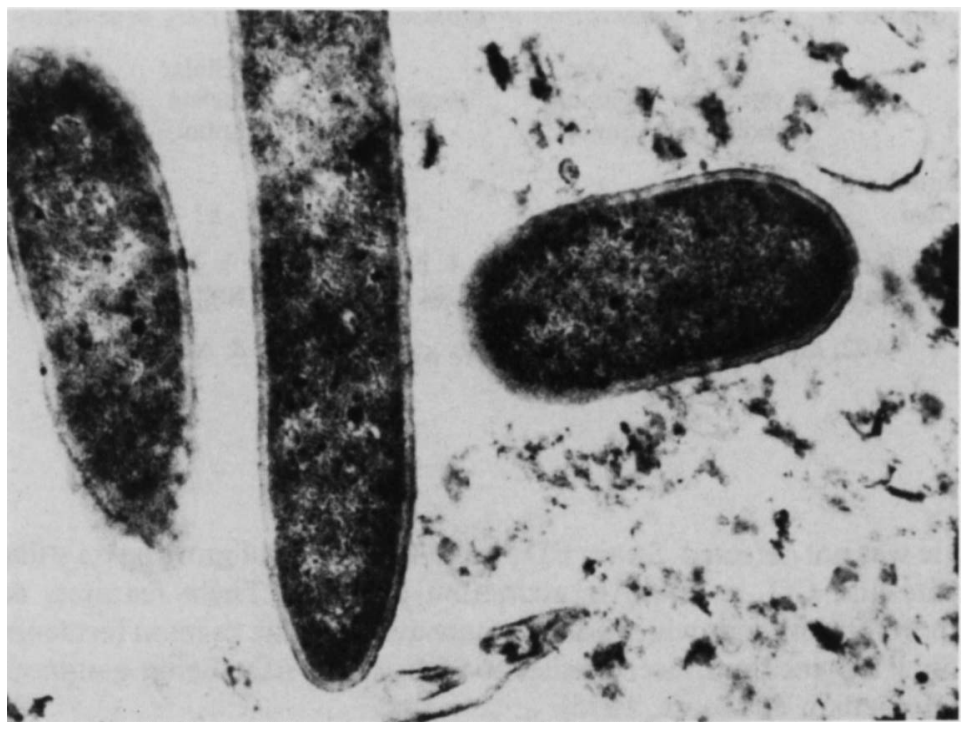

Fig. 1. Electron micrograph of thin sections of organism $E_{3}$. Magnification $\times 41200$.

\section{Table 1. Biochemical tests of organism $E D_{3}$ and Eubacterium limosum}

Symbols: - , negative reaction for $90-100 \%$ of strains; + , positive reaction for $90-100 \%$ of strains; \pm , pH 6.0-7.0; A, acid (pH below 5.5); w, weak reaction (pH 5.5-5.9, sugars); d, 40-60\% of strains positive; numbers (hydrogen) represent abundant (4) to negative on a - to 4 scale.

\section{Characteristics}

Cells motile

Acid produced from:

Arabinose
Cellobiose
Fructose
Glucose
Lactose
Maltose
Mannitol
Mannose
Melezitose
Melibiose
Raffinose
Rhamnose
Sucrose
Trehalose
Xylose

Aesculin hydrolysed

Starch hydrolysed

Gelatin digested

$\mathrm{H}_{2}$ produced

Fatty acids produced* PYG (cultures) PY (cultures)
Organism $\mathrm{ED}_{3}$

E. limosum

* a, acetate; b, butyrate; p, propionate; ib, isobutyrate; iv, isovalerate; l, lactate; s, succinate. Capital letters represent an amount of product equal to or greater than $1 \mathrm{meq}$ per $100 \mathrm{ml}$ culture; small letters represent an amount of product less than $1 \mathrm{meq}$ per $100 \mathrm{ml}$ of culture; products in parentheses are not produced uniformly. 
Table 2. Xylose fermentation in mineral medium of $E D_{3}$ organisms

$\begin{array}{lccccc}\text { Xylose } & \begin{array}{c}\text { Acetate } \\ (\mu \mathrm{mol})\end{array} & \begin{array}{c}\text { Propionate } \\ (\mu \mathrm{mol})\end{array} & \begin{array}{c}\text { Cellular } \\ \text { carbon } \\ (\mu \mathrm{mol})\end{array} & \begin{array}{c}\text { Cell } \\ \text { dry wt } \\ \left(\mathrm{g} \mathrm{l}^{-1}\right)\end{array} \\ \text { Initial } & 417 & - & - & - & - \\ \text { Final } & 316 & 48 & 105 & 83 & 0.002\end{array}$

Carbon recovery: $\{[48(2)+105(3)+83] \div[101(5)]\} \times 100=97 \%$ Electron recovery: $\left\{\left[48(8)+105(14)+83(4 \cdot 22)^{*}\right] \div[101(20)]\right\} \times 100=109 \%$

* 4.22, number of electron equivalents $\mu \mathrm{mol}^{-1}$ (Harris \& Adams, 1979).

Table 2. Lactate was not detected. Strain $\mathrm{ED}_{3}$ was also capable of growing on stillage, producing acetate, butyrate and $\mathrm{CO}_{2}$ as main fermentation products. These features, notably Grampositive non-sporeforming rods which form acetate and butyrate as main fermentation products when grown in PYG medium, are consistent with strain $\mathrm{CD}_{3}$ being assigned to the genus Eubacterium (Holdeman \& Moore, 1975).

Strain $\mathrm{ED}_{3}$ is different from all other Eubacterium species able to produce butyric acid: E. alactolyticym, E. biforme, E. budayi, E. cellulosolvens, E. cylindroides, E. hallii, E. limosum, $E$. monoliforme, $E$. multiforme, $E$. nitrogenes, $E$. plautii, $E$. tortuosum and $E$. ventriosum do not produce acid from xylose, arabinose or melezitose. E. hadrum, E. plexicaudatum, E. ramulus, $E$. rectale, E. ruminanthium and E. saburreum do not digest gelatin. E. brachy, E. dolichum and $E$. nodatum are non-saccharoxlastic species and they do not hydrolyse gelatin.

The $\mathrm{G}+\mathrm{C}$ values for strains of Eubacterium are between 26 and $48 \mathrm{~mol} \%$ (Wegienek \& Reddy, 1982). The melting point $\left(T_{\mathrm{m}}\right)$ for DNA from strain $\mathrm{ED}_{3}$ was $72{ }^{\circ} \mathrm{C}$ (mean of three determinations), from which a DNA base composition of $44 \mathrm{~mol} \%$ was derived. The butyricacid-producing Eubacterium species have the following DNA G + C values (mol \%): E. biforme, $32\left(T_{\mathrm{m}}\right) ;$ E. cylindroides, $31\left(T_{\mathrm{m}}\right) ;$ E. hallii, 36-38 $\left(T_{\mathrm{m}}\right) ;$ E. hadrum, 32-33 $\left(T_{\mathrm{m}}\right) ;$ E. plexicaudatum, $44\left(T_{\mathrm{m}}\right) ;$ E. ramulus, $39\left(T_{\mathrm{m}}\right) ;$ E. rectale, $30\left(T_{\mathrm{m}}\right)$; and E. nodatum, 36-38 $\left(T_{\mathrm{m}}\right)$. The mol \% $\mathrm{G}+\mathrm{C}$ of the DNA for other butyric-acid-producing Eubacterium species has not been determined or reported because of poor growth and difficulty of preparing DNA.

Eubacterium limosum, which seems to be closely related to Clostridium barkeri and Acetobacterium woodii (Balch et al., 1977; Tanner et al., 1981) can use $\mathrm{CO}_{2}$ plus $\mathrm{H}_{2}$ for growth as can strain $\mathrm{ED}_{3}$; however, the difference in DNA base composition (47 versus $44 \mathrm{~mol} \%$ ) indicates that they are distinct taxa. Moreover, E. limosum strains have not been reported to grow with ethanol as carbon source. Similarly, ethanol is not used by Butyribacterium methylotrophicum, which is closely related to Eubacterium. The DNA base composition and growth on ethanol as well as pentoses led us to propose a new species for strain $\mathrm{ED}_{3}$, which is described below.

Eubacterium tucumanense sp. nov. (tu.cu.man.en'se. M.L. adj. tucumanense, native to Tucumán; named after the province of Tucumán, where it was isolated). Cells are straight rods, $0.3-0.5 \mu \mathrm{m} \times 1.5-2 \mu \mathrm{m}$, usually present in pairs, non-motile. Cells stain Grampositive and the cell wall is composed of a single layer. Colonies are punctiform and translucent, with a defined edge; they are about $0.5 \mathrm{~mm}$ in diameter after $21 \mathrm{~d}$ incubation at $37^{\circ} \mathrm{C}$. Cells can grow in defined mineral medium but yeast extract enhances growth. The following compounds support growth: methanol, ethanol, xylose, arabinose, fructose, $\mathrm{CO}_{2}$ plus $\mathrm{H}_{2}$. Cells produce acetate, propionate and hydrogen when grown on xylose. In PY medium, cells also produce small amounts of isobutyrate and isovalerate.

Obligate anaerobe. Optimal growth at $37^{\circ} \mathrm{C}$, grows also at $45^{\circ} \mathrm{C}$ but does not grow at $55^{\circ} \mathrm{C}$. The mol $\% \mathrm{G}+\mathrm{C}$ of the DNA of the type strain, $\mathrm{ED}_{3}$, is 44 . Strain $\mathrm{ED}_{3}$ has been deposited at the American Type Culture Collection as ATCC 49281. 


\section{REFERENCES}

Balch, W. J., Schobert, S., TANner, S. \& Wolfe, R. S. (1977). Acetobacterium, a new genus of hydrogen-oxidizing, carbon-dioxide-reducing, anaerobic bacteria. International Journal of Systematic Bacteriology 27, 355-361.

Balch, W. J., Fox, G. E., Magrum, L. J., Woese, C. R. \& Wolfe, R. S. (1979). Methanogens: reevaluation of a unique biological group. Microbiological Reviews 43, 260-296.

HARRIS, R. F. \& ADAMS, S. A. (1979). Determination of the carbon and electron composition of microbial cells and metabolites by dichromate oxidation. Applied and Environmental Microbiology 37, 237-243.

Holdeman, L. V. \& MoORE, W. E. C. (1975). Anaerobe Laboratory Manual. Blacksburg, Virginia: Virginia Polytechnic Institute.

MANDEL, M. \& MARMUR, J. (1968). Use of ultraviolet absorbance-temperature profile for determining the guanine plus cytosine content of DNA. Methods in Enzymology 12B, 195-206.

MAYER, R. L. \& SCHOBERTH, S. (1977). Electron microscopic investigation of the hydrogen-oxidizing acetate-forming anaerobic bacterium, Acetobacterium woodii. Archives of Microbiology 115, 207-213.

Miller, T. L. \& Wolin, M. J. (1974). A serum bottle modification of the Hungate technique for cultivating obligate anaerobes. Applied Microbiology 27, 985-987.

Moore, W. E. C. \& Holdeman-Moore, L. V. (1986). Genus Eubacterium. In Bergey's Manual of Systema- tic Bacteriology, vol. 2, pp. 1353-1373. Edited by P. H. A. Sneath. Baltimore: Williams \& Wilkins.

Saito, H. \& Miura, K. (1963). Preparation of transforming deoxyribonucleic acid by phenol treatment. Biochimica et biophysica acta 72, 619-629.

TANNer, S. R., Stackebrandt, E., Fox, G. E. \& WOESE, C. R. (1981). A phylogenetic analysis of Acetobacterium woodii, Clostridium barkeri, Clostridium butyricum, Clostridium tituseburense, Eubacterium limosum and Eubacterium tenue. Current Microbiology 5, 35-38.

WegieneK, J. \& Reddy, C. A. (1982). Taxonomic study of Corynebacterium suis Soltys and Spratling: proposal of Eubacterium suis (nom. rev) comb. nov. International Journal of Systematic Bacteriology 32, 218-228.

Wilkins, T. D., Fulghum, R. S. \& Wilkins, J. H. (1974). Eubacterium plexicaudatum sp. nov., an anaerobic bacterium with subpolar tuft of flagella, isolated from a mouse cecum. International Journal of Systematic Bacteriology 24, 408-411.

Wolin, E. A., Wolin, M. J. \& Wolfe, R. S. (1963). Formation of methane by bacterial extracts. Journal of Biological Chemistry 238, 2882-2886.

ZeIKUS, J. G., LYND, L. H., THOMPSON, T. E., Krzycki, J. A., Weimer, P. J. \& Hegge, P. W. (1980). Isolation and characterization of a new, methylotrophic, acidogenic anaerobe, the Marburg strain. Current Microbiology 3, 381-386. 